\title{
Assessment of heavy metal levels in blood of metal forging factory workers in nnewi, Anambra state, Nigeria
}

\author{
A.N. Okpogba ${ }^{1}$, E.C. Ogbodo ${ }^{2 *}$, E.C. Ugwu ${ }^{3}$, C.C. Dike ${ }^{4}$, S.O. Nwoko ${ }^{5}$, A.K. Amah ${ }^{6}$, E.P. Mounmbegna ${ }^{7}$, M.N. \\ Izuogu $^{8}$, E.C. Onyeneke ${ }^{9}$
}

\begin{abstract}
${ }^{1,3,4}$ Dept. of Human Biochemistry, Faculty of Basic Medical Sciences, Nnamdi Azikiwe University, Nnewi Campus, Anambra State, Nigeria, ${ }^{2}$ Department of Medical Laboratory Science, Faculty of Health Sciences and Technology, Nnamdi Azikiwe University, Nnewi Campus, Anambra State, Nigeria, ${ }^{5,7}$ Dept. of Biochemistry, Madonna University, Elele Campus, Rivers State, Nigeria, ${ }^{6}$ Dept. of Human Physiology, College of Medicine, Imo State University, Owerri, Nigeria, ${ }^{8}$ Dept. of Human Anatomy, Faculty of Basic Medical Sciences, Nnamdi Azikiwe University, Nnewi Campus, Anambra State, Nigeria, ${ }^{9}$ Dept. of Biochemistry, University of Benin, Benin City, Edo State,
\end{abstract} Nigeria

\section{*Corresponding Author: E.C. Ogbodo}

Email: augustinee442@gmail.com

\begin{abstract}
Background: Heavy metal toxicity has proved to be a major threat to human health as several health risks are associated with it.

Materials and Methods: This is a cross sectional study designed to assess the heavy metal levels in blood of metal forging factory workers in Nnewi, Anambra State, Nigeria. A total of eighteen (18) apparently healthy subjects from the exposed group (metal forging factory) aged between 19 and 56 years and 79 control subjects (comprising of 39 control subjects from Nnewi (N) and 40 control from Elele (E) respectively) aged between 18 and 44 years were recruited for the study. The body mass index (BMI) and length of service (LOS) of the subjects were obtained using structured questionnaire and thereafter, $10 \mathrm{ml}$ of venous blood sample was collected from each individual for the assessment of heavy metal levels ( $\mathrm{Pb}, \mathrm{Ni}, \mathrm{Cu}, \mathrm{Zn}, \mathrm{As}$ and $\mathrm{Se}$ ) using atomic absorption spectroscopy (AAS).

Results: The result revealed that the body mass index (BMI) of the metal forging factory workers differed significantly compared with control N subjects $(24.75 \pm 0.38)$ and E subjects $(23.58 \pm 0.67)(\mathrm{p}<0.05)$. Factory workers had a length of service (LOS) of $5.74 \pm 1.21$ years. There were significant increases in the mean levels of $\mathrm{Ni}, \mathrm{As}$ and $\mathrm{Pb}$ and decreases in $\mathrm{Cu}, \mathrm{Zn}$ and Se levels in the metal forging factory workers compared with control subjects $(\mathrm{p}<0.05)$ respectively. Metal levels differed significantly with both age and length of service (LOS) in exposed worker compared with control subjects $(\mathrm{p}<0.05)$. Also, Zn level was significantly correlated with LOS of metal forging factory workers $(\mathrm{r}=0.562 ; \mathrm{p}=0.015)$.

Conclusion: This study showed elevated levels of $\mathrm{Ni}, \mathrm{As}$ and $\mathrm{Pb}$ and decreased levels of $\mathrm{Cu}, \mathrm{Zn}$ and $\mathrm{Se}$ in the blood of metal forging factory workers.
\end{abstract}

Keywords: Heavy metal, Metal forging factory, Body mass index (BMI), Length of Service (LOS).

\section{Introduction}

Metal forging is defined as a metal working process in which the useful shape of metal work piece is obtained in solid state by compressive forces applied through the use of dies and tools ${ }^{1}$. Forging process is accomplished by hammering or pressing the metal. It is one of the oldest known metal working processes with its origin about some thousands of years back. Traditionally, forging was performed by a smith using hammer and anvil. Using hammer and anvil is a crude form of forging. In modern times, industrial forging is done either with presses or with hammers powered by compressed air, electricity, hydraulics or steam. ${ }^{1}$

Heavy metals are naturally occurring elements that have a high atomic weight and a density at least five times greater than that of water. ${ }^{2}$ Some debate exists as to exactly what constitutes a "heavy metal" and which elements should properly be classified as such. Some authors have based the definition on atomic weight, while others point to those metals with a specific gravity of greater than 4.0, or greater than 5.0. Most recently, the term "heavy metal" has been used as a general term for those metals and semimetals with potential human or environmental toxicity. ${ }^{3}$ Heavy metal toxicity has proved to be a major threat as several health risks are associated with it. These metals have hardly any biological role to play in the human body but on the contrary their toxic effect causes malfunctioning of the body system. ${ }^{4}$ Anthropogenic activities such as seen in metal forging factories contribute significantly to environmental contamination. These metals are systemic toxicants known to induce adverse health effects in humans, including cardiovascular diseases, developmental abnormalities, neurologic and neurobehavioral disorders, diabetes, hearing loss, hematologic and immunologic disorders, and various types of cancer. ${ }^{5}$ The main pathways of exposure include ingestion, inhalation, and dermal contact. The severity of adverse health effects is related to the type of heavy metal and its chemical form, and is also time and dose-dependent. In biological systems, heavy metals have been reported to affect cellular organelles and components such as cell membrane, mitochondria, lysosome, endoplasmic reticulum, nuclei, and some enzymes involved in metabolism, detoxification, and damage repair. ${ }^{6}$ Metal ions have been found to interact with cell components such as DNA and nuclear proteins, causing DNA damage and conformational changes that may lead to cell cycle modulation, carcinogenesis or apoptosis. ${ }^{7}$ These elements may sometimes act as pseudo elements of the body, interfering with the metabolic processes that occur in the body. Metal toxicity depends on the absorbed dose, its route as well as 
duration of exposure. These heavy metals bind with protein sites which are not meant for them, by displacing original metals from their natural binding sites causing malfunctioning of cells by their toxicity. ${ }^{4}$ These heavy metals include; Cadmium, zinc, copper, lead, nickel, cobalt, arsenic, selenium, mercury and so on. These heavy metals, when they accumulate in the human body result in toxicity which causes several systemic health conditions especially in workers who are by their occupation exposed to them.

Maria et al. observed higher levels of heavy metals especially $\mathrm{Pb}$ in metal factory workers ${ }^{8}$. Muhammad also had a similar finding in which he observed significantly higher concentrations of toxic metals in the blood, urine, and saliva samples of exposed workers than in the control subjects ${ }^{9}$. The finding of Draz et al. ${ }^{10}$ was also in keeping with the observations of Maria et $a l^{8}$ and Muhammed. ${ }^{9}$ However, Draz and his team observed no significant difference in blood metal levels in the different age groups and between both sexes in the factory workers group. ${ }^{10}$ Therefore, this study assessed the heavy metal levels in blood of metal forging factory workers in Nnewi, Anambra State, Nigeria.

\section{Materials and Methods}

\section{Study Design and Participant Recruitment}

This is a cross-sectional study designed to assess heavy metal levels in blood of metal forging factory workers in Nnewi, Anambra State, Nigeria. A total of eighteen (18) apparently healthy subjects in the exposed group (metal forging factory workers) aged between 19 and 56 years were recruited for the study. The exposed group comprised workers from metal forging factory who were constantly being exposed to effluents from the factory. The control groups were made up of two (2) sets: The first set was made up of thirty-nine (39) staff and undergraduate students of the College of Health Sciences, Nnamdi Azikiwe University, Nnewi Campus whose residential homes were at least 5-10 $\mathrm{km}$ from the factory sites, while the second set was made up of forty (40) staff and undergraduate students of the Faculty of Medicine, Madonna University, Elele. They were aged between 18 and 44 years. Informed consent was obtained from all individuals after being educated on the benefit of the study and completing of a structured questionnaire. Thereafter, $10 \mathrm{ml}$ of venous blood sample was collected from each individual for the evaluation of heavy metal levels. Blood samples for the determination of lead $(5 \mathrm{ml})$ were delivered into new EDTA containers, mixed and stored frozen at $-4^{0} \mathrm{C}$ until analyzed. The rest of the blood sample was delivered into lithium heparin containers and then centrifuged for 3 minutes at $2000 \mathrm{rpm}$. The plasma were separated and put into clean dry sample containers and stored deep-frozen at $-4^{0} \mathrm{C}$ until analyzed. The plasma was used for the estimation of heavy metals ( $\mathrm{Pb}, \mathrm{Ni}, \mathrm{Cu}, \mathrm{Zn}, \mathrm{As}$ and $\mathrm{Se}$ ) by atomic absorption spectroscopy (AAS) according to the method of Smith et al. ${ }^{11}$ Determination of lead in whole blood was done using the method as described by Hessel. $^{12}$

\section{Inclusion Criteria}

Apparently healthy subjects aged between 19 and 56 years who are exposed to metal forging factory effluents and control subjects (non-exposed groups) were included in this study.

\section{Exclusion Criteria}

Individuals of any known kidney disease, liver disorder, alcoholics and smokers as well as those outside the age limits were excluded from the study.

\section{Ethical Consideration}

Ethical approval for the research was obtained from Ethical Committee, Nnamdi Azikiwe University Teaching Hospital, Nnewi, Anambra State, Nigeria (NAUTH/CS/66/Vol.2/149).

\section{Statistical Analysis}

The data were presented as mean \pm SEM and the mean values of the control and test group were compared by Student's ttest and Pearson's bivariate correlation coefficient using Statistical package for social sciences (SPSS) (Version 16) software. A $\mathrm{P}<0.05$ was considered as significant.

\section{Results \\ Demographic Profiles}

The metal forging factory had the length of service (LOS) of $5.74 \pm 1.21$ years. The age, weight and body mass index (BMI) of the metal forging factory workers differed significantly when compared with control $\mathrm{N}$ subjects $(24.75 \pm 0.38)$ and $\mathrm{E}$ subjects $\quad(23.58 \pm 0.67) \quad(\mathrm{p}<0.05)$ respectively. See table 1 .

Table 1: Some demographic profiles of metal forging factory workers

\begin{tabular}{|c|c|c|c|c|c|}
\hline Factory & Age (yrs) & LOS (yrs) & Weight (kg) & Height (m) & BMI (kg/m $\mathbf{m}^{\mathbf{2}}$ \\
\hline $\mathrm{N}(\mathrm{n}=39)$ & $23.28 \pm 0.91^{\mathrm{ab}}$ & & $74.82 \pm 1.04^{\mathrm{c}}$ & $1.74 \pm 0.01^{\mathrm{b}}$ & $24.75 \pm 0.38^{\mathrm{b}}$ \\
\hline $\mathrm{E}(\mathrm{n}=40)$ & $21.68 \pm 0.33^{\mathrm{a}}$ & & $66.10 \pm 10.91^{\mathrm{b}}$ & $1.68 \pm 0.01^{\mathrm{a}}$ & $23.58 \pm 0.67^{\mathrm{b}}$ \\
\hline $\mathrm{K}(\mathrm{n}=18)$ & $26.17 \pm 1.45^{\mathrm{b}}$ & $5.74 \pm 1.21$ & $58.00 \pm 1.92^{\mathrm{a}}$ & $1.65 \pm 0.02^{\mathrm{a}}$ & $21.37 \pm 0.69^{\mathrm{a}}$ \\
\hline
\end{tabular}

Values are in mean $( \pm$ SEM); within the column, means with different superscripts are statistically significant $(\mathrm{p}<0.05)$. Key:

N: $\quad$ Control subjects from Nnewi

E: $\quad$ Control subjects from Elele

K: $\quad$ Workers from metal forging factory 
BMI: Body mass index

LOS: Length of service

Metal levels of control ( $\mathrm{N}$ and $\mathrm{E})$ subjects and metal forging factory workers

The mean $\mathrm{Ni}$, As and $\mathrm{Pb}$ levels were significantly elevated in metal forging factory workers than in control $\mathrm{N}$ subjects $(0.04 \pm 0.00)$ and control E subjects $(0.07 \pm 0.00),(\mathrm{p}<0.05)$ respectively. However, the mean concentrations of $\mathrm{Cu}, \mathrm{Se}$ and $\mathrm{Zn}$ were significantly reduced in the metal forging factory workers when compared with the control subjects respectively $(\mathrm{p}<0.05)$. See table 2.

Table 2: Metal levels of metal forging factory workers

\begin{tabular}{|c|c|c|c|c|c|c|}
\hline Factory & $\mathbf{N i}(\boldsymbol{\mu m o l} / \mathbf{L})$ & $\mathbf{C u}(\boldsymbol{\mu m o l} / \mathbf{L})$ & $\mathbf{Z n}(\boldsymbol{\mu m o l} / \mathbf{L})$ & As $(\boldsymbol{\mu m o l} / \mathbf{L})$ & Se $(\boldsymbol{\mu m o l} / \mathbf{L})$ & $\mathbf{P b}(\boldsymbol{\mu m o l} / \mathbf{L})$ \\
\hline $\mathbf{N}(\mathbf{n}=\mathbf{3 9})$ & $0.04 \pm 0.00^{\mathrm{a}}$ & $16.69 \pm 0.21^{\mathrm{c}}$ & $11.73 \pm 0.19^{\mathrm{d}}$ & $0.01 \pm 0.00^{\mathrm{a}}$ & $5.11 \pm 0.08^{\mathrm{c}}$ & $0.59 \pm 0.07^{\mathrm{a}}$ \\
\hline $\mathbf{E}(\mathbf{n}=\mathbf{4 0})$ & $0.07 \pm 0.00^{\mathrm{a}}$ & $19.72 \pm 0.21^{\mathrm{d}}$ & $17.11 \pm 0.46^{\mathrm{e}}$ & $0.02 \pm 0.00^{\mathrm{a}}$ & $6.66 \pm 0.08^{\mathrm{d}}$ & $0.79 \pm 0.10^{\mathrm{b}}$ \\
\hline $\mathbf{K}(\mathbf{n}=\mathbf{1 8})$ & $2.56 \pm 0.07^{\mathrm{b}}$ & $9.06 \pm 0.19^{\mathrm{e}}$ & $7.11 \pm 0.14^{\mathrm{c}}$ & $0.02 \pm 0.00^{\mathrm{bc}}$ & $2.59 \pm 0.17^{\mathrm{a}}$ & $0.85 \pm 0.02^{\mathrm{c}}$ \\
\hline
\end{tabular}

Values are in mean \pm SEM; within the column, means with different superscripts are statistically significant ( $<<0.05$ ).

Key:

N: Control subjects from Nnewi

E: Control subjects from Elele

K: Workers from metal forging factory

The effects of age on metal levels of metal forging factory workers

The effects of age on metal levels of factory workers are presented in Table 3 while the regression analyses are presented in Figure 1. $\mathrm{Ni}$, As and $\mathrm{Pb}$ levels in all the age groups were significantly elevated $(\mathrm{p}<0.05)$ compared with controls $\mathrm{N}$ and $\mathrm{E}$ subjects while $\mathrm{Cu}, \mathrm{Zn}$ and Se levels were significantly reduced $(\mathrm{p}<0.05)$. Highest metal levels were obtained in the range 30$40 \mathrm{yrs}$ for $\mathrm{Ni}$, As and $\mathrm{Pb}$, however, reduced $\mathrm{Zn}$ and $\mathrm{Se}$ levels were obtained in the 30-40yrs while $\mathrm{Cu}$ in the 18-30yrs groups. The regression coefficients of $\mathrm{Ni}$, As and $\mathrm{Se}$ of $0.083,0.100$ and 0.325 , respectively showed that these metals were positively correlated with age while $\mathrm{Cu}(\mathrm{r}=-0.012), \mathrm{Zn}(\mathrm{r}=-0.425)$ and $\mathrm{Pb}(\mathrm{r}=-0.151)$ were negatively correlated.

Table 3: Effect of age on heavy metal levels of metal forging factory workers

\begin{tabular}{|l|l|l|l|l|l|l|}
\hline Age group & $\mathbf{N i}(\boldsymbol{\mu m o l} / \mathbf{L})$ & $\mathbf{C u}(\boldsymbol{\mu m o l} / \mathbf{L})$ & $\mathbf{Z n}(\boldsymbol{\mu m o l} / \mathbf{L})$ & $\mathrm{As}(\boldsymbol{\mu m o l} / \mathbf{L})$ & $\mathbf{S e}(\boldsymbol{\mu m o l} / \mathbf{L})$ & $\mathbf{P b}(\boldsymbol{\mu m o l} / \mathbf{L})$ \\
\hline $\mathbf{N}(\mathbf{n}=39)$ & $0.04 \pm 0.00^{\mathrm{a}}$ & $16.69 \pm 0.21^{\mathrm{b}}$ & $11.73 \pm 0.19^{\mathrm{b}}$ & $0.01 \pm 0.00^{\mathrm{a}}$ & $5.11 \pm 0.08^{\mathrm{b}}$ & $0.59 \pm 0.01^{\mathrm{a}}$ \\
\hline $\begin{array}{l}\mathbf{1 8 - 3 0 y r s} \\
(\mathbf{n}=14)\end{array}$ & $2.57 \pm 0.09^{\mathrm{b}}$ & $9.17 \pm 0.21^{\mathrm{a}}$ & $7.18 \pm 0.17^{\mathrm{a}}$ & $0.02 \pm 0.00^{\mathrm{b}}$ & $2.71 \pm 0.08^{\mathrm{a}}$ & $0.86 \pm 0.02^{\mathrm{b}}$ \\
\hline $\begin{array}{l}\mathbf{3 0 - 4 0 y r s} \\
(\mathbf{n}=\mathbf{2})\end{array}$ & $2.66 \pm 0.11^{\mathrm{b}}$ & $8.11 \pm 0.18^{\mathrm{a}}$ & $7.17 \pm 0.40^{\mathrm{a}}$ & $0.02 \pm 0.00^{\mathrm{b}}$ & $2.61 \pm 0.07^{\mathrm{a}}$ & $0.89 \pm 0.08^{\mathrm{b}}$ \\
\hline $\begin{array}{l}\mathbf{4 0 - 5 0 y r s} \\
(\mathbf{n = 2})\end{array}$ & $2.58 \pm 0.17^{\mathrm{b}}$ & $9.14 \pm 0.04^{\mathrm{a}}$ & $7.10 \pm 0.01^{\mathrm{a}}$ & $0.02 \pm 0.00^{\mathrm{b}}$ & $3.25 \pm 0.58^{\mathrm{a}}$ & $0.81 \pm 0.03^{\mathrm{b}}$ \\
\hline
\end{tabular}

Values are in mean $( \pm$ SEM); within column, means with different superscripts are statistically significant $(\mathrm{p}<0.05)$

Key:

$\mathbf{N}$ : Control subjects

The effect of LOS on metal levels of metal forging factory workers

Table 4 presents the effect of LOS on metal levels of factory workers while Figure 2 presents the regression of metal levels with LOS. There were significant differences $(p<0.05)$ between all the metal levels in all the LOS groups and the controls $\mathrm{N}$ and $\mathrm{E}$ subjects with elevated levels of $\mathrm{Ni}, \mathrm{As}$ and $\mathrm{Pb}$ and reduced levels of $\mathrm{Cu}, \mathrm{Zn}$ and $\mathrm{Se}$. The highest levels of $\mathrm{Ni}$ and $\mathrm{Pb}$ were recorded in the 11-15yr group while As was in the 6-10yr group. Except for $\mathrm{Zn}(\mathrm{r}=0.562 ; \mathrm{p}=0.015)$ which was significantly correlated $(\mathrm{p}<0.05)$ with LOS, Ni ( $\mathrm{r}=-0.371 ; \mathrm{p}=0.130), \mathrm{Cu}(\mathrm{r}=-0.145 ; \mathrm{p}=0.567), \mathrm{Se}(\mathrm{r}=-0.185 ; \mathrm{p}=0.463)$ and $\mathrm{Pb}$ $(\mathrm{r}=-0.450 ; \mathrm{p}=0.061) \mathrm{Ni}, \mathrm{Cu}, \mathrm{As}, \mathrm{Se}$ and $\mathrm{Pb}$ were negatively correlated but non-significantly $(\mathrm{p}>0.05)$ with LOS. 

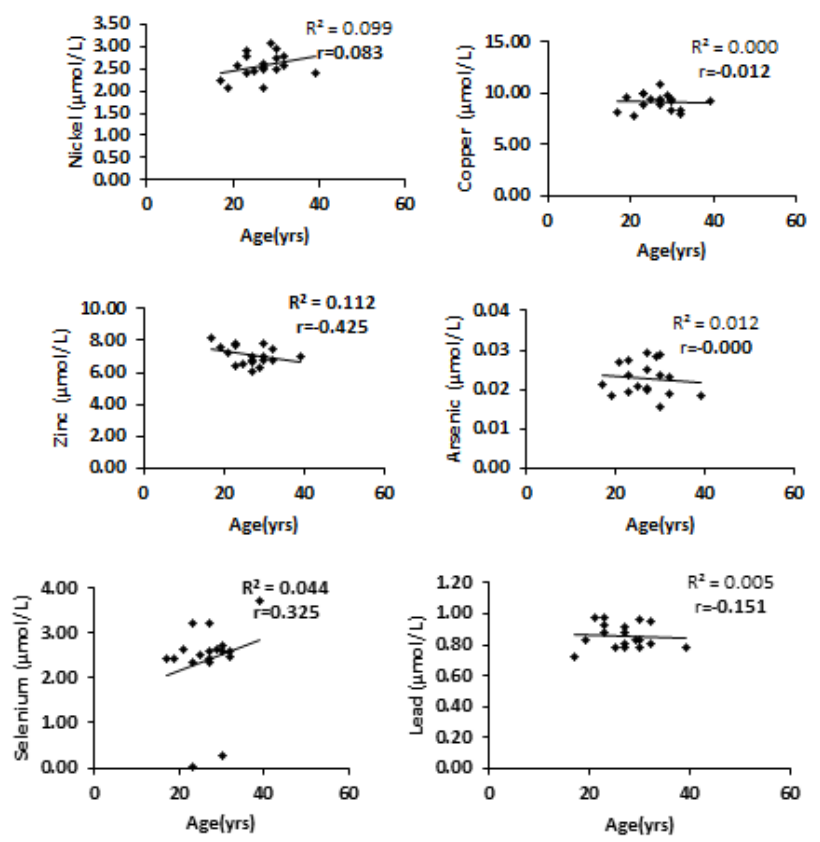

Fig. 1: Regression of metal levels of metal forging factory workers with age

Table 4: Effect of LOS on heavy metal levels of metal forging factory workers

\begin{tabular}{|c|c|c|c|c|c|c|}
\hline LOSgroup & $\mathrm{Ni}(\mu \mathrm{mol} / \mathrm{L})$ & $\mathrm{Cu}(\mu \mathrm{mol} / \mathrm{L})$ & $\mathrm{Zn}(\mu \mathrm{mol} / \mathrm{L})$ & $\mathrm{As}(\mu \mathrm{mol} / \mathrm{L})$ & $\operatorname{Se}(\mu \mathrm{mol} / \mathrm{L})$ & $\mathrm{Pb}(\mu \mathrm{mol} / \mathrm{L})$ \\
\hline $\mathrm{N}(\mathrm{n}=39)$ & $0.04 \pm 0.00^{\mathrm{a}}$ & $16.69 \pm 0.21^{b}$ & $11.73 \pm 0.19^{6}$ & $0.01 \pm 0.00^{\mathrm{a}}$ & $5.11 \pm 0.08^{b}$ & $0.59 \pm 0.01^{\mathrm{a}}$ \\
\hline $0-5$ yrs $(\mathrm{n}=12)$ & $2.59 \pm 0.07^{\mathrm{c}}$ & $9.09 \pm 0.24^{\mathrm{a}}$ & $6.93 \pm 0.15^{\mathrm{a}}$ & $0.02 \pm 0.00^{\mathrm{b}}$ & $2.82 \pm 0.13^{\mathrm{a}}$ & $0.88 \pm 0.02^{\mathrm{b}}$ \\
\hline 6-10yrs (n=2) & $2.75 \pm 0.20^{\mathrm{cd}}$ & $8.82 \pm 0.53^{\mathrm{a}}$ & $7.73 \pm 0.16^{\mathrm{a}}$ & $0.03 \pm 0.01^{b}$ & $2.61 \pm 0.07^{\mathrm{a}}$ & $0.80 \pm 0.02^{\mathrm{b}}$ \\
\hline $11-15 y \operatorname{ss}(\mathrm{n}=2)$ & $2.83 \pm 0.09^{\mathrm{d}}$ & $9.22 \pm 0.12^{\mathrm{a}}$ & $7.33 \pm 0.24^{\mathrm{a}}$ & $0.02 \pm 0.00^{\mathrm{b}}$ & $2.81 \pm 0.14^{\mathrm{a}}$ & $0.89 \pm 0.05^{\mathrm{b}}$ \\
\hline $15-20$ yrs $(\mathrm{n}=2)$ & $2.13 \pm 0.08^{b}$ & $8.83 \pm 0.74^{\mathrm{a}}$ & $7.91 \pm 0.26^{\mathrm{a}}$ & $0.02 \pm 0.00^{\mathrm{b}}$ & $2.51 \pm 0.01^{\mathrm{a}}$ & $0.78 \pm 0.05^{\mathrm{b}}$ \\
\hline
\end{tabular}

Values are in mean $( \pm$ SEM); within column, means with different superscripts are statistically significant $(\mathrm{p}<0.05)$

KEY:

N: $\quad$ Control subjects

LOS: Length of service
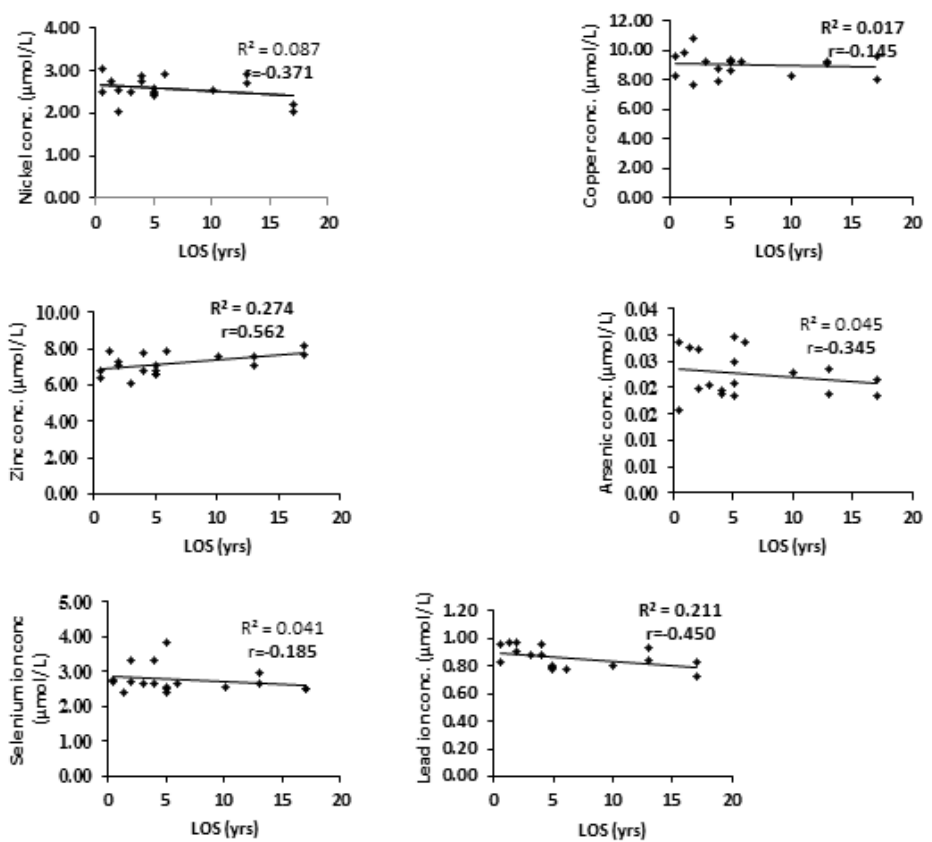


\section{Effect of gender on factory workers' Metal levels}

The effect of gender on the metal levels of the factory workers is presented in Table 5. There was no significant difference ( $p>0.05$ ) between the $\mathrm{Ni}, \mathrm{Cu}, \mathrm{Zn}, \mathrm{As}, \mathrm{Se}$ and $\mathrm{Pb}$ levels of male and female workers of the metal forging factory.

Table 5: Effect of gender on metal levels of metal forging factory workers

\begin{tabular}{|l|l|l|l|l|l|l|l|}
\hline Factories & $\mathrm{Gender}$ & $\mathrm{Ni}(\mu \mathrm{mol} / \mathrm{L})$ & $\mathrm{Cu}(\mu \mathrm{mol} / \mathrm{L})$ & $\mathrm{Zn}(\mu \mathrm{mol} / \mathrm{L})$ & $\mathrm{As}(\mu \mathrm{mol} / \mathrm{L})$ & $\mathrm{Se}(\mu \mathrm{mol} / \mathrm{L})$ & $\mathrm{Pb}(\mu \mathrm{mol} / \mathrm{L})$ \\
\hline $\mathrm{N}$ & $\mathrm{M}(\mathrm{n}=29)$ & $0.37 \pm 0.02^{\mathrm{a}}$ & $16.90 \pm 0.24^{\mathrm{d}}$ & $11.85 \pm 0.23^{\mathrm{d}}$ & $0.01 \pm 0.00^{\mathrm{a}}$ & $4.05 \pm 0.01^{\mathrm{c}}$ & $0.59 \pm 0.01^{\mathrm{a}}$ \\
\hline & $\mathrm{F}(\mathrm{n}=10)$ & $0.38 \pm 0.03^{\mathrm{a}}$ & $16.50 \pm 0.48^{\mathrm{d}}$ & $11.06 \pm 0.30^{\mathrm{d}}$ & $0.01 \pm 0.00^{\mathrm{a}}$ & $4.07 \pm 0.12^{\mathrm{c}}$ & $0.59 \pm 0.03^{\mathrm{a}}$ \\
\hline $\mathrm{E}$ & $\mathrm{M}(\mathrm{n}=18)$ & $0.08 \pm 0.01^{\mathrm{a}}$ & $20.99 \pm 0.35^{\mathrm{f}}$ & $16.29 \pm 0.39^{\mathrm{e}}$ & $0.02 \pm 0.00^{\mathrm{ab}}$ & $6.53 \pm 0.13^{\mathrm{d}}$ & $0.85 \pm 0.02^{\mathrm{c}}$ \\
\hline & $\mathrm{F}(\mathrm{n}=22)$ & $0.05 \pm 0.00^{\mathrm{a}}$ & $18.66 \pm 0.36^{\mathrm{e}}$ & $17.79 \pm 0.76^{\mathrm{f}}$ & $0.02 \pm 0.00^{\mathrm{b}}$ & $6.76 \pm 0.10^{\mathrm{d}}$ & $0.74 \pm 0.02^{\mathrm{b}}$ \\
\hline $\mathrm{K}$ & $\mathrm{M}(\mathrm{n}=8)$ & $2.60 \pm 0.09^{\mathrm{b}}$ & $8.91 \pm 0.30^{\mathrm{ab}}$ & $7.21 \pm 0.24^{\mathrm{b}}$ & $0.02 \pm 0.01^{\mathrm{b}}$ & $2.26 \pm 0.32^{\mathrm{a}}$ & $0.86 \pm 0.03^{\mathrm{c}}$ \\
\hline & $\mathrm{F}(\mathrm{n}=10)$ & $2.51 \pm 0.09^{\mathrm{b}}$ & $9.18 \pm 0.24^{\mathrm{ab}}$ & $7.14 \pm 0.17^{\mathrm{ab}}$ & $0.02 \pm 0.00^{\mathrm{b}}$ & $2.85 \pm 0.14^{\mathrm{a}}$ & $0.84 \pm 0.02^{\mathrm{c}}$ \\
\hline
\end{tabular}

Values are in mean $( \pm$ SEM $)$; within column, means with different superscripts are statistically significant $(\mathrm{p}<0.05)$

\section{KEY:}

$\mathbf{N}$ : Control subjects from Nnewi

E: Control subjects from Elele

K: Workers from metal forging factory

M: Male

\section{F: Female}

\section{Discussion}

Heavy metals are significant environmental pollutants and their toxicity is a problem of increasing significance for ecological, evolutionary, nutritional and environmental reasons. ${ }^{13}$ Heavy metal toxicity has proven to be a major threat to human health with several health risks associated with it. ${ }^{14}$ The most commonly found heavy metals in waste water include arsenic, cadmium, chromium, and copper, lead, nickel, and zinc, all of which cause risks for human health and the environment ${ }^{15}$. The present study investigated the heavy metal $(\mathrm{Ni}, \mathrm{Cu}, \mathrm{Zn}, \mathrm{As}, \mathrm{Se}$ and $\mathrm{Pb})$ levels in the blood of metal forging factory workers in Nnewi town in Anambra State, South eastern Nigeria.

In this study, the mean age of the control subjects were $(23.28 \pm 0.91)$ and $(21.68 \pm 0.33)$ years for control $\mathrm{N}$ and $\mathrm{E}$ subjects respectively with the metal forging factory workers having a mean age of $(26.17 \pm 1.45)$ years. This shows that the studied subjects were from a young, active and vibrant population which forms the major part of the manufacturing sector of the economy. Further, the mean body mass index of the metal forging factory workers were significantly lower compared with the control subjects and had a mean length of service (LOS) of $5.74 \pm 1.21$ years.

Expectedly, the mean nickel (Ni) level was significantly elevated in the metal forging factory worker than in control subjects. This is in consonance with the previous report of Okpogba et al. who showed an elevated level of $\mathrm{Ni}$ in the blood of metal fabricating factory workers in Nnewi. ${ }^{16}$ This result may be as a result of the environmental pollution occurring in the area under study. Environmental nickel levels depend especially on natural sources, pollution from nickel-manufacturing industries and airborne particles from combustion of fossil fuels. ${ }^{17}$ Nickel is released into the atmosphere during nickel mining and the industrial production of stainless steel and other nickel alloys, or by industries that use nickel and its compounds. ${ }^{18}$ The elevated level of $\mathrm{Ni}$ in this study may suggest that the exposed persons could suffer the effect of Ni toxicity. Previous report indicates that nickel is a potential immunomodulatory and immunotoxic agent aside from its action as an allergen in humans. ${ }^{19-20}$

In the present study, the mean serum level of copper $(\mathrm{Cu})$ was significantly reduced in metal forging factory workers than in control subjects. This is in keeping with previous studies. ${ }^{21,16}$ Copper is needed by the body for a number of functions, predominantly as a cofactor for a number of enzymes such as ceruloplasmin, cytochrome oxidase, dopamine $\beta$-hydroxylase, superoxide dismutase and tyrosinase. ${ }^{22}$ Therefore, depletion of $\mathrm{Cu}$ level may have negative implications for the affected persons.

Also, the mean serum levels zinc ( $\mathrm{Zn})$ and selenium (Se) was significantly reduced in metal forging factory workers than in control subjects. This is in contrast with the finding of Okpogba et al. on the heavy metal levels in chickens (gallus gallus domestica) in rural (Elele) and urban (Nnewi) areas. ${ }^{23}$ This disparity in the result may be due to the fact that the birds were not exposed directly to the heavy metals as is in the case of the metal forging factory workers.

However, the mean levels lead $(\mathrm{Pb})$ and arsenic (As) was significantly elevated in the metal forging factory workers compared to the control subjects. This is in agreement with the findings of some previous similar studies ${ }^{24,25,16}$. Also, Ziad et al. showed higher levels of $\mathrm{Pb}$ in Jordanian automobile workers which further agrees with the present result ${ }^{26}$. The elevated levels of both lead and arsenic recorded in this study may imply that the exposed subjects in this study may experience lead and arsenic toxicities over time and hence, they are prone to suffering from the deleterious effects of both metals. Lead has been found to impair development and have harmful effects even at lower levels. ${ }^{27,28}$ Lead toxicity has been implicated as a potential cause of a wide range of multisystem defects or disorders in humans including impaired respiratory function, ${ }^{29}$ infertility, ${ }^{30}$ brain damage, renal defects and liver defects among others. ${ }^{31-33}$ Recognizably, the most potent mechanism by which lead affects various systems of the human body is via its ability to induce oxidative stress by generating reactive oxygen species. On the other hand, As can induce cancer, genotoxicity and affect the hematopoietic 
system, liver, kidneys, skin and brain ${ }^{34}$. Arsenic also exerts its toxicity by generating reactive oxygen intermediates during redox cycling and metabolic activation processes that cause lipid peroxidation and DNA damage. ${ }^{35}$ Therefore, the elevated levels of lead and arsenic found in this study demands urgent health interventions.

Interestingly, $\mathrm{Ni}, \mathrm{As}$ and $\mathrm{Pb}$ levels were significantly elevated while $\mathrm{Cu}$, Se and $\mathrm{Zn}$ levels were reduced in all age groups than in control subjects respectively. No gender based difference was observed in metal levels studied in factory workers when compared with control subjects. However, Zn level was significantly correlated with length of service (LOS) of factory workers.

\section{Conclusion}

This study showed elevated levels of Nickel, Arsenic and Lead and decreased copper, Selenium and Zinc levels in metal forging factory workers than in control subjects respectively. There was no gender based differences observed in metal levels studied in factory workers when compared with control subjects. However, Zn level was significantly correlated with length of service (LOS) of factory workers $(\mathrm{r}=0.562 ; \mathrm{p}=0.015)$.

\section{Conflict of Interest: None.}

\section{References}

1. Mahendra G, Rathi N, Jakhade A. An Overview of Forging Processes with their Defects. Int J Scientific Res Public 2014;4:6.

2. Oijagbe IJ, Abubakar BY, Edogbanya PRO, Suleiman MO, Olorunmola JB. Effects of heavy metals on soil microbial biomass carbon. Med Crave Online J Biol Med 2019; 4:1.

3. Saunders JE, Jastrzembski BG, Buckey JC. Hearing loss and heavy metal toxicity in a nicaraguan mining community: audiological results and case reports. $J$ Audiol Neurotol 2013;18(2):101-113.

4. Alkesh IS. Heavy metal impact on aquatic life and human health-an overview. Annual Conference of the International Association for Impact Assessment 2017;1-7.

5. Paul BT, Clement G, Yedjou A, Patlolla K, Dwayne JS. Heavy Metals Toxicity and the Environment. Nat Center Biotechnol Inform 2014;101:133-64.

6. Wang S, Shi X. Molecular mechanisms of metal toxicity and carcinogenesis. J Mol Cellular Biochem 2001;222:3-9.

7. Beyersmann D, Hartwig A. Carcinogenic metal compounds: recent insight into molecular and cellular mechanisms. Arch Toxicol 2008;82(8):493-512.

8. Maria F, Romero-Zarazua JL, Sanchez-Salas MA, QuirozAlfaro ER, Bandala M, Endez-Rojas AM et al. Occupational exposure to heavy metals in a metal-mechanical auto part manufacturing plant in Puebla. Mexican Int J Environ Health $2015 ; 4: 8$.

9. Muhammad J. Evaluating levels and health risk of heavy metals in exposed workers from Surgical Instrument manufacturing Industries of Sialkot, Pakistan. Environ Sci Pollution Res 2016;23(18):1-5.

10. Draz E, El- Kelany R, El- Nimr T, Badawy A, Zakaria S. Role of selenium and vitamin e in occupational exposure to heavy metals (mercury, lead and cadmium): impact of working in lamp factory. Mansoura J Forensic Med Clin Toxicol 2009;17:2.
11. Smith JC (Jr), Butrimovitz GP, Purdy WC. Direct measurement of zinc in plasma by atomic absorption spectrometry. Clin Chem 1979;125:1487.

12. Hessel DW. A simple and rapid quantitative determination of lead in blood. Atomic Absorpt Newsletter 1968;7:50-55.

13. Nagajyoti PC, Lee KD, Sreekanth TVM. Heavy metals, occurrence and toxicity for plants: a review. Environ Chem Letters 2010;8(3):199-216.

14. Monisha J, Tenzin T, Naresh A, Blessy BM, Krishnamurthy NB. Toxicity, mechanism and health effects of some heavy metals. Interdiscip Toxicol 2014;7(2):60-72.

15. Lambert M, Leven BA, Green RM. New methods of cleaning up heavy metal in soils and water. Environmental science and technology briefs for citizens. Kansas State University, Manhattan, KS, 2000.

16. Okpogba ANgozyka, Ogbodo EC, Mounmbegna EP, Izuogu $\mathrm{MN}$, Amah AK, Onyeneke CE. Assessment of heavy metal levels in blood of metal fabricating factory workers in Nnewi, Nigeria. Santosh Univ J Health Sci 2019;5(1):

17. Das KK, Reddy RC, Bagoji IB, Das S, Bagali S, Mullur L, et al. Primary concept of nickel toxicity - an overview. J Basic Clin Physiol Pharmacol 2019;30(2):141-52.

18. Cameron KS, Buchner V, Tchounwou PB. Exploring the Molecular Mechanisms of Nickel-Induced Genotoxicity and Carcinogenicity: A Literature Review. Rev Environ Health 2011;26(2):81-92.

19. Nielsen FH. Clinical and biochemical nutritional aspects of trace elements. New York: Alan R. Liss Inc; 1982. Possible future implications of nickel, arsenic, silicon, vanadium, and other ultra trace elements in human nutrition; Pp. 379-404.

20. M'Bemba-Meka P, Lemieux N, Chakrabarti SK. Role of oxicative stress, mitochondrial membrane potential, and calcium homeostasis in human lymphocyte death induced by nickel carbonate hydroxide in vivo. Arch Toxicol 2006;80(7):405-20.

21. El Safty A, El Mahgoub K, Helal S, Abdel MN. Zinc toxicity among galvanization workers in the iron and steel industry. Ann N Y Acad Sci 2008;1140:256-262.

22. Badiye A, Kapoor N, Khajuria H. Copper Toxicity: A Comprehensive Study. Res J Recent Sci 2013;2:58-67.

23. Okpogba AN, Ogbodo EC, Ugwu EC, Oguaka VN, Dike CC, Ujowundu FN et al. Comparative assessment of heavy metal levels in chickens (gallus gallus domestica) in rural (elele) and urban (nnewi) areas. Asian J Sci Technol 2018;09 (11):905659.

24. Damastuti E, Adventini N, Syahfitri WYN, Kurniawati S, Lestiani DD, Santoso M et al. Assessment Of Heavy Metals On Occupationally Exposed Workers From Hair Analysis. Atom Indonesia 2017;43(3):119-126.

25. Job EE, Ogbodo EC, Ogbu ISI, Analike RA, Onuora IJ, ObiEzeani CN, et al. Determination of Blood Levels of Lead in Pregnant Women in Nnewi, Anambra State, South Eastern Nigeria. Saudi J Med Pharm Sci 2018;4(11):1338-42.

26. Ziad S, Darwish B, Abdelrahim H, Abdelkader B. Association between occupational lead exposure and plasma levels of selected oxidative stress related parameters in Jordanian automobile workers. Int J Occup Med Environ Health 2018;31(4):517-25.

27. Barbosa F, Jr, Tanus-Santos JE, Gerlach RF, Parsons PJ. A critical review of biomarkers used for monitoring human exposure to lead: advantages, limitations, and future needs. Environ Health Perspect 2005;113:1669-74.

28. Rossi E. Low Level Environmental Lead Exposure - A Continuing Challenge. Clin Biochem Rev 2008;29:63-70.

29. Jurdziak M, Gać P, Martynowicz H, Poręba R. Function of respiratory system evaluated using selected spirometry parameters in persons occupationally exposed to lead without 
evident health problems. Environ Toxicol Pharmacol 2015;39:1034-40.

30. Flora G, Gupta D, Tiwari A. Toxicity of lead: A review with recent updates. Interdiscip Toxicol 2012;5:47-58.

31. Needleman H. Lead poisoning. Аппи Rev Med 2004;55:20922.

32. Grant LD. Lead and compounds. Environmental Toxicants, John Wiley \& Sons Inc, Hoboken, New Jersey, United States, 2008;757-809.

33. Bukola RO, Adeleke AA, Omamuyovwi MI, Stephen OA. Lead-induced damage on hepatocytes and Hepatic reticular fibres in rats; protective role of aqueous extract of Moringa oleifera leaves (lam). J Biosci Med 2015; 3:27-35.

34. Halatek T, Sinczuk-Walczak H, Rabieh S, Wasowicz W. Association between occupational exposure to arsenic and neurological, respiratory and renal effects. Toxicol Appl Pharmacol 2009;239:193-9.

35. Cobo JM, Castineira M. Oxidative stress, mitochondrial respiration, and glycemic control: clues from chronic supplementation with $\mathrm{Cr} 3+$ or As3+ to male Wistar rats. Nutr 1997;13:965-70.

How to cite this article: Okpogba AN, Ogbodo EC, Ugwu EC, Dike CC, Nwoko SO, Amah AK, Mounmbegna EP, Izuogu MN, Onyeneke EC. Assessment of heavy metal levels in blood of metal forging factory workers in nnewi, Anambra state, Nigeria. J Pharm Biolog Sci 2019;7(1):34-40. 